\title{
The effect of music Mnemonic and Flash Cards to increase fourth grade students' english vocabulary acquisition
}

\author{
Unike Nathania Winoto, Srisiuni Sugoto, Ananta Yudiarso \\ Faculty of Psychology \\ Universitas Surabaya \\ Surabaya, Indonesia \\ srisiuni@staff.ubaya.ac.id
}

\begin{abstract}
The purpose of this quasi-experimental study was to examine the effect of music mnemonic and flash cards in enhancing grade 4 students' English vocabulary acquisition. The participants were 30 students, aged 9-11 years old, who had low capability in second language (English) vocabulary acquisition. The result of the study showed that music mnemonic and flash cards could increase students' vocabulary acquisition, $p=0.001$; $\mathrm{p}<0.01$. Music mnemonic group has the highest score due to the multimodality of the various methods of memorization that impact to the chunking effect on working memory, so that the new information can be more easily to transfer to the long-term memory. Teachers and school should combine several methods in providing appropriate learning based on the students' cognitive development stage.
\end{abstract}

Keywords—music mnemonic; flash cards; English vocabulary; elementary students

\section{INTRODUCTION}

The next development process requires the individual to begin performing a form of language adjustment and to understand the second language (L2). English is an International language taught in most schools in Indonesia. English learning should be supported by the vocabulary mastery. Vocabulary that must be mastered by 4th grade elementary school is formulated from the Standards Competency and Basic Competencies set by the government related to the English subject for grade 4 elementary school.

Suyanto (2013) explains that the obstacles causing the students cannot learn a second language well are: 1) lack of motivation, 2) learning materials that are too difficult, 3) methods or language learning media tend to be less attractive, and 4) lack habituation due to the English subject matter [16]. Indah (2013) in his research on Arabic learning strategy, suggests that in learning a second language, it is necessary to include methods or materials that are enjoyable for students [2].

The theory of memory structure suggests the existence of three parts of memory, namely sensory memory, Short-Term Memory, and Long-Term Memory [15]. New information can be entered and processed in the system memory in a way or method that bridges the information. Then, the information is stored well in Long-Term Memory. One of the strategies used to help the information to survive in Long-Term Memory is by rehearsal (maintenance rehearsal).

Previous research on the vocabulary methodology suggests that repetition methods can give a good impact to the one's vocabulary mastery. The research of Hardjosoesanto and Siswanto (2014) provided a feedback that the method of repetition does not give any difference to the students' vocabulary mastery. Marretsya's research (2013) explains that the animated images forgotten by students will have an impact on the vocabulary that the students memorized [9]. The image can serve as a student's facility in memorizing, although when the image is forgotten, the information can go missing as the image disappears from the student's memory.

The application of the repetition method can also be followed by the involvement of the sense device. Giving applications that involve these sensory devices, can be through various ways, such as with a picture card or song. Strategies that can be done to help the process of memorization is with mnemonic. Mnemonics is a strategy to assist a person in organizing information to reach the maximum stage of longterm memory [5].

Mnemonic music is a method of remembering information by making the information into a song [11]. Mnemonics are various strategies and tricks for improving the ability to remember, such as the use of poetry or formulas [17].

The use of music in this study uses children's music that is liked by children since grade 1 to 4 elementary school. The use of images in this study uses interesting and colorful images. The purpose of this research is to know the influence of intervention method memorize with mnemonic music and picture card to the mastery of English vocabulary of 4th grade students. 


\section{METHOD}

The research design used is quasi-experimental research design. This research used a design named between subject design [7]. The pre-test-post-test design is a design that compares the pre-test value with the post-test value obtained by the participants.

In this research, EG1, EG2, and CG will be formed. EG1 is a group that gets repetitive treatment with mnemonic music, EG2 is a group that gets repetition with picture cards, and CG is a group that only gets repetition without media.

The study participants were the 4th graders at an Elementary School $\mathrm{X}$ in Surabaya. The sample of study participants was conducted without randomization (nonrandomized), but selected based on the sample characteristics (purposive sampling). The characteristics of the sample in this study are as follows.

1. The subjects have an interest in music, singing, and have an interest in pictures,

2. The subjects have an equivalent level of intelligence between experimental groups,

3. The subjects have the ability to mastery vocabulary in the medium to low range. The capability of moderating vocabulary is derived from the results of the last English test score (all under 7.0).

The procedures performed at the pre-experimental stage were vocabulary measurements in the early stages prior to the intervention, measuring students' intelligence tests using CFIT $2 \mathrm{~A}$ tests, composing a good method of mnemonic music and picture cards, selecting some teachers who have no experiences in the study, and provide explanations to the teachers. In the experimental stage, there were 3 sessions for each method and 60 minutes per session. In the postexperimental stage, the posttest value or the end result of the vocabulary mastery and the follow-up is done a week after the posttest measurement without any additional intervention.

The instruments of this study are three, namely music, cards picture, and a matter of vocabulary test. The measurement of the validity was using content validity, taking into account the value of CVI.

The measuring tool used are in the form of 90 questions with a short answer that represents the Vocabulary Competency Standard of English students grade IV and measured its reliability with Kuder Richardson-20 ( $\mathrm{p}=0.958$, close to 1.00).

The method used to analyze the data in this study is the Covariance Analysis (ANAKOVA).

\section{RESUltS AND DISCUSSION}

Normality test is performed to test the normality of data distribution both on pretest and on posttest. The normality test was performed using Kolmogorov-Smirnov.

The results of normality test of data distribution at pretest gained the value $p=0.120$ where $p>0.05$, it can be said that the result of the pretest is normal. The normality test data distribution on the posttest gained the value $\mathrm{p}=0.200$ where $\mathrm{p}$ $>0.05$, it means that the result of the posttest is normal.

The homogeneity test was conducted to determine the variance of two or more variables used in the study. The tests were performed using Levene's Test.

The homogeneity test results indicate that all data used in this study is homogeneous or have the same variance. This can be seen from the acquisition of a $\mathrm{p}$ value greater than 0.05 on the overall test result.

The hypothesis testing is done by using covariance analysis. The control variables that were used as a comparison in this study were the students' IQ test scores as well as the latest English test score obtained by the students.

The result of the analysis shows that there is an influence of method to the students' vocabulary score. It indicated from the significance value of 0.001 (less than 0.05 ) which means the method has an influence on the students' English vocabulary test score. IQ scores have no effect on the vocabulary test scores. This is shown from the significance value of 0.766 (more than 0.05 ).

It can be seen that the Experiment Group 1 is ranked as the highest when it is measured by posttest and then followed it up. While the experiment Group 2 also experienced the same increase as the Experiment Group 1, but at the Follow-up, the experiment group 2 was decreased. The control group is at the lowest position in the graph.

In this research, there are 4 vocabulary themes given to the students. The theme given is part of the body, family member, school life, and home sweet home. From the results of the analysis, it is obtained that on the theme of school life and family members, students have a lower value compared to other themes. This low value is not in the control group, but rather the group with mnemonic music interventions and picture cards.

In this study, interviews were also conducted on student representation from each group. Interviews were conducted on 1 subject with the highest score and 1 subject with the lowest score in each group. The interview was gathered from 6 participants.

The questions presented to the subject are about the fun of the lessons that have been given, the obstacles faced by the students while learning, and the feeling of the subject when learning with a particular method that is different from that he usually receives in the daily school activities.

The result of the research shows the influence of mnemonic and pictorial card to the mastery of English vocabulary of 4 th grade students $(p=0.001 ; p<0.01)$. The average score of vocabulary mastery in experiment group 1 was 72.6. The average score of vocabulary mastery in experiment 2 group was 64.9. The mean score of vocabulary mastery in the control group was 52.1. The experimental group 1 had the highest average vocabulary score compared to the experimental group 2 and the control group. 
The results of this study support the other research that has been done by Maghy (2015) on the effectiveness of mnemonic music method in academic learning at school. The method of mnemonic music becomes a method that capable in bridging the process of the brain performance [8]. The same result of the study from Köksal, Yaĝişan, and Çekiç (2013) indicates that teaching new vocabulary through music has significantly increased achievement in English vocabulary learning. This is due to the influence of music that can balance the performance of the right and left hemisphere of the brain [13].

Sacks (2007) describes how the brain works with the music. Music that enters the memory system in the brain can be automatically understood by someone. Sacks (2007) explains that the song which lyrics have been replaced by the vocabulary that is about to be put into memory, has a chunking effect to the memory of the students [13]. This is due to the recall of songs being learned when the process of entering information from STM to LTM. Chunking effect is related to the grouping of melodies with the existing vocabulary in the lyrics of the song. This causes a student to recall more easily with the existence of facilities such as songs or music.

A research conducted by Pikulski \& Templeton (2014) on the effectiveness of the method of memorizing to improve vocabulary mastery also explains that in learning the language or vocabulary required the involvement of brain activity [12]. This is because in memorization will involve memory, and the main memory performance is in the brain activity. The combination of learning methods in learning new information is part of multimodality. Multimodality (Jewitt, 2005) is a combination of several methods of processing information in working memory [3]. The working process of memory supported by multimodality will help new information fit into Long-Term Memory.

The group who received the picture card intervention scored below the group who received the mnemonic music intervention. Picture cards are a facility used by visual methods, where participants with pictorial card methods may only use vision to view images. The results showed that groups with picture cards also had better grades or had different vocabulary mastery than those who did not get any method. This supports previous research conducted by Gelfgren (2012) which suggests that the pictorial card method is a medium that can be used for visual teaching methods, or that involves seeing [1]. McGraw, Yoshimoto, and Seneff (2009) also showed the result of their research that a novel application for speech technology could aid students with vocabulary acquisition in a foreign language through interactive card games [10].

Rising scores on the control group are interesting to discuss. Subjects who are 4 th graders of elementary school are the subject to the age of 10 years and can be classified at the stage of concrete operational cognitive development. According to Piaget $[14,11,4]$, the stage of the development of concrete operations requires the child to be able to think logically and begin to use clear rules, but only with objects that are concrete.
A 10-year-old student has been able to classify, group, and issue settings.

Age 10 is a good age to start learning a second language (L2). English as a second language for children is a new language, which children must master in addition to the development of the first language (L1). The second language (L2) can begin to be learned because of the help of previous language mastery. A child who has good Indonesian language skills, it is possible to have good English skills when the bridge between Indonesia and English language is facilitated by good and appropriate methods.

Vocabulary mastery scores were allegedly influenced by other variables such as students' intelligence abilities in this study. The results of the calculations show that the students' English vocabulary mastery has no interaction with the results of the Intelligence Test score. This is shown from the value of $\mathrm{p}=0.776(\mathrm{p}>0.05)$ indicating that there is no interaction between the students' English vocabulary mastery with the score of the Intelligence Test.

Language learning or vocabulary involves many aspects of one's memory. One of the most influential in the memory process is the organization of information [15]. This information organization aims to distinguish and simplify information stored in memory. The organization of this information is determined by the context of the vocabulary or vocabulary theme. The context also affects how one absorbs the new information. Context effects have been observed in related studies of perceptual memory by using stimulation of geometric shapes, random shapes, and semiabstract images [15].

\section{CONCLUSION}

This study resulted in the finding that mnemonic music and picture cards are effective in improving students' English vocabulary mastery. This proves that the process mechanism of multimodality, chunking effect and repetition give good impact to the working process of memory in managing new information in the form of English vocabulary.

The result of intelligence tests didn't have a strong correlation in this study. The intelligence test variable is a control variable that controls all subjects in this study. The theme of vocabulary in this study is 4 . The theme is the theme of body parts, school activities, parts of the house, and family members.

Of the four themes, there is one theme that is beyond the context of the children aged 10 years understanding.

\section{REFERENCES}

[1] C. Gelfgren, "Language learning strategies: Theory and research", in ILI Language Teaching Journal, Vol. 2 (1). Iran, 2012

[2] T.L. Indah, "Pengaruh metode menghafalkan berulang dengan pengelompokan (chunking) untuk membantu menghafalkan Al-Qur'an pada siswa SD". Unpublished research. FKIP Universitas Islam Negeri Wali Songo, 2013 
[3] C. Jewitt, “'Reading', and 'writing' for the 21st century", in Discourse Studies in the Cultural Politics of Education, Vol. 26 (3), pp 315-331, 2005

[4] R. V. Kail, "Children and their development (4th Ed.)". New Jersey: Pearson Education, Inc, 2007

[5] S. Khan, "Music works: Music for adult English language learners", in New Directions for Adult and Continuing Education Vol. 107, pp 13-21, 2003

[6] O. Köksal, N. Yaĝişan, \& A. Çekiç, "The effects of music on achievement, attitude and retention in primary school English lessons", in Procedia - Social and Behavioral Sciences vol. 93. pp1897-1900, 2013

[7] Latipun, Psikologi eksperimen. Malang: UMM Press, 2004

[8] S.J. Maghy, "Effectiveness of mnemonics on achievement of students in mathematics at high school level", in International Journal of Modern Engineering Research (IJMER), Vol. 5 (4), 2015

[9] Y. Marretsya, "Pengenalan kosakata Bahasa Inggris melalui penggunaan media animasi gambar pada kelompok B Raflesia kota Bengkulu" Thesis. Bengkulu: Universitas Bengkulu, 2013
[10] I. McGraw, B. Yoshimoto, \& S. Seneff, "Speech-enabled card games for incidental vocabulary acquisition in a foreign language", in Speech Communication, 51, pp 1006-1023, 2009

[11] D.E, Papalia, S.W. Olds, \& R.D. Feldman, A child's world: Infancy through adolescence (10th Ed.). Boston: McGraw Hill, 2006

[12] J.J. Pikulski,, \& S. Templeton, "Teaching and Developing Vocabulary: Key to Long-Term Reading Success", in Research in Language and Reading. Houghton Mifflin Company, USA, SHA15M1203, G-23748, 2014

[13] N. Sacks, "Review article: instructed second language vocabulary learning", in Language Teaching Research, Vol 12 (3), pp 329-363, 2007

[14] C.K. Sigelman, \& E.A. Rider, Life-span human development. Belmont: Wadsworth/Thomson Learning, Inc, 2003

[15] R.L. Solso, O.H. Maclin, \& M.K. Maclin, Psikologi kognitif (8th Ed.). Jakarta: Penerbit Erlangga, 2008

[16] K. Suyanto, Psikolinguistik. Jakarta: Gramedia Pustaka Utama, 2013

[17] C. Wade, \& C. Tavris, Psikologi (9th Ed. 2nd Vol.). Jakarta: Penerbit Erlangga, 2007 